\title{
Statistical Literacy and its Urgency for Students
}

\author{
Yuniawatika \\ Faculty of Education, State University of Malang, Indonesia \\ yuniawatika.fip@um.ac.id
}

\begin{abstract}
The issue of literacy has been widely studied by education experts both at home and abroad, including statistical literacy. Statistical literacy is an important thing for productive people to have in this 4.0 industrial revolution era. Statistical literacy is the ability to interpret and describe information that we often encounter in everyday life. Is that simple statistical literacy? What is statistical literacy? can anyone with statistical knowledge be said to have statistical literacy skills? How to develop statistical literacy skills among students? This paper will generally try to answer these questions.
\end{abstract}

Keywords: statistical, literacy, students, ability, statistical literacy

\section{INTRODUCTION}

Statistics is an important component of the mathematics curriculum. In the principles and standards of school mathematics evaluation, NCTM includes the contents of "Data Analysis and Probability" in one of the five content standards, which include Numbers and Number Operations, Algebra, Geometry, Data and Probability, and Measurement. The importance of statistics is also one of the scope of mathematics in the 2013 curriculum. K 2013 curriculum in elementary schools there is three scopes studied by students, namely numbers, geometry and measurement, and data processing. In junior high, the scope of mathematics load number, algebra, geometry and measurement, as well as s Statistica and opportunities. Whereas in high school it contains algebra, geometry, statistics and opportunities, trigonometry, and calculus. Based on the scope of mathematics and NCTM it can be seen that statistics is one of the important scopes of mathematics because it is learned to start with basic education. This is in line with the opinion of Franklin et al. [1] which states that statistics are a key component of the mathematics curriculum.

Not only in basic education and secondary education, statistics are studied, but up to higher education statistics are studied by students. If you look closely at the statistics studied aiming at statistical literacy. Mastery of statistical literacy is considered very important to be owned by human resources in this 4.0 revolution era so that it becomes part of the Education program. In a wider scope, this statistical literacy program makes human resources literate.

With the development of science and technology that quickly raises various increasingly complex problems. Problems that are increasingly complex can certainly be solved with the help of many and varied information. One information that is spread can be in the form of statistical data, so that the ability to read, interpret, and conclude data is important to have and that is an important part of statistical literacy. Thus, this statistical literacy skill needs to be owned primarily by students who will be involved in the world of work and become the next generation of the nation. This is in line with Gal's opinion [2] that statistical literacy is a key ability that is expected to be owned by each individual starting from school age and will be indispensable as an adult. Of course, to improve this statistical literacy ability, observers of Education need to understand what statistical literacy is. In fact, according to Murray [3] not only observers of Education are responsible for the increase in statistical literacy but producers and journalists are also responsible in terms of improving statistical literacy. Thus, this statistical literacy ability needs to be owned by all circles.

\section{Statistical Literacy}

Statistical literacy is one of the new literacy in addition to the old literacy of reading, writing, and arithmetic which is the basic capital to survive in this era. Digital literacy is needed by digital society to help interpret and describe information from events that often appear in various types of information both in the real world and cyberspace. The definition of statistical literacy is very large and continues to grow. In general, statistical literacy is defined as statistical literacy or literacy. Wallman [4] argues that statistical literacy is the ability to understand and evaluate statistical results in everyday life critically accompanied by the ability to appreciate the contribution of statistical thinking. According to Gal [2], The statistical literacy is the ability to interpret, critically evaluate statistical information, and communicate information and statistical messages. Meanwhile, delMas [5] stated that statistical literacy is the ability to translate and evaluate every statistical data circulating in the community through various communication media. In addition, according to Forbes [6], statistical literacy is communicating messages in the form of products of words, numbers, and graphics.

Based on the definition of these experts, it can be seen that statistical literacy is the ability to understand, interpret, evaluate, and communicate statistical data through various media critically. The ability to understand here include an understanding of symbols, terms, statistics language, presentation of data in a graph or table, and be able to make the connection between statistical data. The ability to interpret, and evaluate can be understood as a person's ability to read data and analyze based on the statistical knowledge he already has. In addition, it is able to predict general trends from a graph and proceed with drawing conclusions based on existing data. Meanwhile, communicating statistical messages can be through 
tables, diagrams, graphs or words that support the delivery of messages effectively and efficiently.

Based on the above understanding, it implies statistical literacy not only in mastering the material but also in the use of reasoning, concepts, facts, and mathematical tools in problem-solving. In addition, statistical literacy also requires someone to communicate and explain the phenomena they face and become an element that supports a person's statistical literacy abilities.

The indicators or basis of statistical literacy according to Martadiputra [7] includes the following: (1) reasoning of data; (2) reasoning of basic statistical concepts and terms used in statistics; (3) reasoning for data collection and processing in descriptive statistics; (4) basic ability to translate data; and (5) basic ability in communicating data and research results. Based on these indicators, we can know that the statistical literacy ability in question is not just about understanding statistical knowledge but can be seen as the reasoning ability used to be statistical literacy. So the aspect of thinking and reasoning is an integral part of statistical literacy. According to Gal [2], statistical literacy involves elements of knowledge and disposition elements described in the table below.

Table 1

A Model Of Statistical Literacy

\begin{tabular}{|l|l|}
\hline \multicolumn{1}{|c|}{ Knowledge elements } & Dispositional elements \\
\hline $\begin{array}{l}\text { Literacy skills } \\
\text { Statistical knowledge } \\
\text { Mathematical knowledge } \\
\text { Context knowledge } \\
\text { Critical Questions }\end{array}$ & Beliefs and Attitudes \\
\hline \multicolumn{2}{|c|}{ Critical stance } \\
\hline \multicolumn{2}{|c|}{ Statistical Literacy } \\
\hline
\end{tabular}

Based on the Table 1 above it can be seen that statistical literacy skills not only require statistical science but there are other elements of knowledge namely literacy skills, mathematical knowledge, and knowledge context. Of course, basic literacy is the capital of statistical literacy, namely writing, reading, and counting. Considering all statistical data can be submitted through written or oral text or table or graphic information display that requires basic literacy skills. Given the importance of basic literacy skills, this literacy ability needs to be possessed so as not to become an obstacle in statistical literacy. According to Scheaffer, Watkins, \& Landwehr in Gal [2] says about the prerequisites of statistical knowledge, namely: number sense, understanding variables, interpreting tables and graphs, understanding planning aspects (such as determining good samples, data collection methods, and preparing instruments), understand the process of data analysis, understand the relationship between probability and statistics, and the reasons for inferential selection. Based on the above opinion, it can be seen that the prerequisites for statistical knowledge include mathematical knowledge such as number sense, variables, tables, and graphs.
Furthermore, context knowledge is the main determinant because context knowledge is a source of meaning and the basis for interpretation of the results obtained. If you are not familiar with the context of a data it will have difficulty interpreting and concluding from a data even allowing for errors to occur. The last of the elements of knowledge is the ability to access critical questions and to support critical attitudes supported by certain beliefs and attitudes that are part of other elements, namely elements of disposition. These elements cannot operate independently of each other. All of these elements become an interdependent, dynamic element that can shape statistical literacy behavior.

\section{DeVelop Literacy Statistics in StUdents}

Statistics is not a new thing for students, because statistics have been studied by students ranging from elementary to high school. Besides being studied in school, statistics are close to everyday life. Simply put, with statistics we can do simple inferences such as reading data in a data presentation and presenting data which will certainly be easier to understand such as the presentation of table data, graphs, diagrams, and so on. Without understanding statistics, the information presented becomes meaningless and meaningless. With statistical literacy allows one to be more productive. Of course, every individual needs to study statistics and become statistical literate. This is in line with Hafiyusholeh's opinion [8] that statistical literacy is important to have and is one component of someone who is Statistical literacy is the ability to understand and be able to criticize data or information he obtained is good from others as well as formal institutions such as the Central Board Statistics.

Statistical literacy needs to be cultivated because it is very important in everyday life and state life. For the community, it will certainly be the basis for choosing a potential leader. Likewise for politicians so that it is not mistaken in interpreting data, because data can also be used in preparing the vision and mission of the regional head. In addition, in our activities, we are required to make decisions based on statistical data. In addition, an early warning system with data can prevent unwanted disasters. It is also important for the government to overcome all the problems of poverty, malnutrition, and unemployment so that it is not wrong in determining a policy that affects the people. Then there is nothing wrong if all parties are encouraged to improve statistical literacy skills.

Dasari [9] provide three examples of events that can provide an overview of how that community modern requires statistical literacy skills. First, many newspapers present graphics or data on the front page. Through the presentation of information statistically try to create a scientific impression so that the news can be trusted. Secondly, more and more large corporate companies are setting policies for almost all of their employees to teach some basic statistical concepts. In this context, statistics become an instrument for an economic value of success. Third, often a political and economic policy involves statistical information in the process. 
Citizen which has a good statistical literacy can make statistical data into quantitative facts and information effectively to choose legislative candidates wiser. Thus it is expected to create a critical and democratic society. In the world of work, for example, statistical literacy also has a vital role. Although today Our performance has been helped a lot by computers, we need to have statistical literacy skills to understand a data and develop it as needed.

In addition, according to Takaria [10] Ability of statistical literacy for students is very important and needs to be improved, this is because 1) the statistical literacy abilities possessed can help students in understanding statistical information well and can be used to make the right decision; 2) can help students in writing their thesis related to the processing and analysis of research data; 3) can respond to problems and activities in the community related to statistical information. With its statistical literacy skills, students are expected to be able to respond to the information they obtain and can evaluate, and finally be able to make decisions about the problems being studied.

There are many more problems in everyday life that require literacy skills, especially statistical literacy. Starting from simple things to complex ones. Thus, the need for statistical competence in modern society is indispensable so if we want our society to have adequate statistical literacy skills, then we need to teach statistical data analysis to students as early as possible.

The importance of statistics is inversely proportional to students' assumptions about statistics. Students still think that statistics is difficult science, full of complicated formulas that require accuracy and accuracy in their calculations. This is in line with the opinion of Ben-Zvi, D., \& Garfield, JB [11] that statistical ideas and rules are complicated, difficult, and made great lazy students involved in the statistics. In addition, too many students have difficulty with the mighty math (such as fractions, decimals, algebraic expressions) that are the basis for the study of statistics so that almighty increasingly unmotivated students to learn statistics. Based on this statement it can be seen that not a few, especially in students experiencing difficulties in understanding statistical language, or can be said to be weak statistic literacy of students. If students do not understand the concept and meaning of the language, students will have difficulties in its application in the field of research and daily life.

Based on these problems, one of the actors who can develop statistical literacy in universities is a lecturer. According to Ferligoj [12], it is very important for educators, especially lecturers in universities, to have statistical literacy and pedagogical tools to provide quality learning so that they can develop and deepen the understanding of statistics so that they are statistically literate. One that can develop students' statistical literacy skills is through the learning model. There are many learning models that can develop student statistical literacy skills. Some of them are collaborative learning [10], contextual learning [13], and problembased learning [14]. The learning confronts contextual problems or real problems in the learning process that will help students construct their knowledge. At this stage, students will solve problems that can be obtained from the internet, mass media, journals, and other sources. In this way, they can use their statistical literacy skills while developing it.

Based on the findings of Takaria [10], that by collaborating can facilitate students in understanding statistical material well, especially how they are trained to construct ideas individually in understanding statistical information (determining the main idea, seeing relationships and differences), and can present information in tables or chart. While Noviasari's findings [14] Problem Based Learning (PBM) can be said to be effective for training junior high school students' statistical literacy on the statistical material. Students experience an increase in statistical literacy skills in the medium and high categories. In addition, Khaerunnisa [13] suggests that lecturers need to use contextual learning strategies in order to improve the ability to formulate problems, use concepts, facts, procedures, and reasoning, as well as the ability to interpret (interpret) problems to solve problems.

Based on the statement above, collaborative learning, contextual learning, and problem-based learning can be used as an alternative to developing statistical literacy, especially for students. In addition, according to Takaria [10] lecturers must be able to create a pleasant learning atmosphere, so statistics that are full of mathematical calculations are seen as something that is interesting and does not cause anxiety for students. With an interesting learning process will make students realize the importance of statistical literacy skills in their life activities. Students who have good statistical literacy will be able to handle quantitative decisions that arise at work and are able to make good decisions about life issues. In other words, students will be able to think critically about the information or data they read.

\section{Conclusion}

The main purpose of writing this paper is to discuss the urgency of statistical literacy for students. Statistical literacy is described as the ability to understand, interpret, evaluate, and communicate statistical data through various media critically. Of course, this statistic literacy skills will work properly if supported by five basic elements of knowledge, namely literacy, knowledge of statistical, mathematical knowledge, critical, and the context of the knowledge that is supported by certain beliefs and attitudes that are part of other elements, element disposition. Both elements are interdependent, dynamic, and can shape statistical literacy behavior.

Given the importance of statistical literacy skills, the effort is needed in order to develop these capabilities. Education has an important role in making it happen. Collaborative learning and problem-based learning is one alternative that can be used to develop statistical literacy. In addition, in learning, students should be given the opportunity to solve problems in various situations related to physics. So that students will activate their statistical literacy and be able to develop it. 


\section{REFERENCES}

[1] C. Franklin et al., "Guidelines for assessment and instruction in statistics education (GAISE) report," Alex. Am. Stat. Assoc., 2007.

[2] I. Gal, "Adults' statistical literacy: Meanings, components, responsibilities," Int. Stat. Rev., vol. 70, no. 1, pp. 1-25, 2002.

[3] S. Murray and I. Gal, "Preparing for diversity in statistics literacy: Institutional and educational implications," in Proceedings of the Sixth International Conference on Teaching of Statistics. Ciudad del Cabo: IASE. CD ROM, 2002.

[4] K. K. Wallman, "Enhancing statistical literacy: Enriching our society," J. Am. Stat. Assoc., vol. 88, no. 421, pp. 1-8, 1993.

[5] R. C. DelMas, "Statistical literacy, reasoning, and thinking: A commentary," J. Stat. Educ., vol. 10, no. 2, 2002.

[6] S. Forbes, M. Camden, N. Pihama, P. Bucknall, and M. Pfannkuch, "Official statistics and statistical literacy: They need each other," Stat. J. IAOS, vol. 27, no. 3, 4, pp. 113-128, 2011.

[7] B. A. P. Martadiputra, "Kajian Tentang Kemampuan Melek Statistis (statistical Literacy), Penalaran Statistis (statistical Reasoning), Dan Berpikir Statistis (statistical Thinking) Guru Smp," Saung-Guru, vol. 83, 2010.

[8] M. Hafiyusholeh, "Literasi Statistik dan Urgensinya Bagi Siswa," WAHANA, vol. 64, no. 1, pp. 1-8, 2015.

[9] D. Dasari, "Kemampuan literasi statistis dan implikasinya dalam pembelajaran," in Prosiding, Seminar Nasional Pendidikan Matematika yang diselengggarakan oleh FMIPA UNY, 2006.

[10] J. Takaria, "Literasi Statistis Dalam Pembelajaran Kolaboratif."

[11] D. Ben-Zvi and J. B. Garfield, The challenge of developing statistical literacy, reasoning and thinking. Springer, 2004.

[12] A. Ferligoj, "How to Improve Statistical Literacy?," Metodoloski $Z v$., vol. 12, no. 1, p. 1, 2015.

[13] E. Khaerunnisa and A. S. Pamungkas, "Profil Kemampuan Literasi Statistis Mahasiswa Jurusan Pendidikan Matematika Universitas Sultan Ageng Tirtayasa," AKSIOMA J. Program Studi Pendidik. Mat., vol. 6, no. 2, pp. 246-255, 2017.

[14] E. Noviasari, "Efektivitas penerapan pembelajaran berbasis masalah untuk melatih literasi statistik siswa SMP pada pada materi Statistika Kelas VII," $\mathrm{PhD}$ Thesis, UIN Sunan Ampel Surabaya, 2017. 